\title{
Biggest Problem
}

National Cancer Institute

\section{Source}

National Cancer Institute. Biggest Problem. NCI Thesaurus. Code C121372.

The largest difficulty, disorder, or condition needing resolution. 